\title{
EFEKTIFITAS DOSIS MINYAK PALA UNTUK PEMINGSANAN IKAN NILA (Oreochromis niloticus) SELAMA TRANSPORTASI
}

\author{
DOZE EFFECTIVITY OF PALA OIL FOR TILAPIA (Oreochromis niloticus) FAINTING WHILE \\ TRANSPORTATION
}

\author{
Munawwar Khalil ${ }^{1)}$, Yuskarina ${ }^{2)}$, Prama Hartami ${ }^{1)}$
}

\begin{abstract}
This research was done on $08^{\text {th }}-10^{\text {th }}$ August, 2011 at Countryside of Alue Keurinyai Banda Baro District, North Aceh Sub-province, Aceh Province. The aim of this research was to know doze effectivity of pala oil for tilapia (oreochromis niloticus) fainting while transportation. This research used non factorial completely randomized treatment with three replications on each treatments that using 0,$8 ; 0,9 ; 1$ and 1,1 ppm doze. The test observed in this research was the speed of fainting fish, insensible recovery, and survival rate on each treatments. Result showed us that the fourth experiment was the speedest faint, while the first experiment was the speedest insensible recovery. While in survival rate, the first experiment was showed the best result, where the percentage value reachs 58,33\%. Based on statistical analyze showed that $f$ count $>f$ table in $99.99 \%$ level of trust for all tested observe.
\end{abstract}

Keywords: Fish Fainting, Oreochromis niloticus, Pala Oil.

\section{PENDAHULUAN}

\section{Latar Belakang.}

Ikan nila (Oreochromis niloticus) merupakan spesies yang berasal dari kawasan Sungai Nil dan danau-danau sekitarnya di Afrika. Bentuk tubuh memanjang, pipih kesamping dan warna putih kehitaman. Jenis ini merupakan ikan konsumsi air tawar yang banyak dibudidayakan setelah ikan mas (Cyprinus carpio) dan telah dibudidayakan lebih dari 85 negara. Saat ini, ikan ini telah tersebar ke negara beriklim tropis dan subtropis, sedangkan pada wilayah beriklim dingin tidak dapat hidup dengan baik. Nila disukai oleh kalangan masyarakat karena mudah dipelihara, dapat dikonsumsi oleh segala lapisan masyarakat serta rasa daging yang enak dan tebal. Tekstur daging ikan nila memiliki ciri tidak ada duri kecil dalam dagingnya. Apabila dipelihara di tambak akan lebih kenyal, dan rasanya lebih gurih, serta tidak berbau lumpur.

Harga ikan hidup empat kali lipat lebih tinggi dibanding dengan ikan mati, sehingga perlu diperhatikan beberapa teknik transportasi agar ikan tetap hidup di tangan konsumen. Dari penelitian terdahulu telah diperolah informasi bahwa transportasi ikan dalam bentuk hidup dapat dilakukan dengan menggunakan bahan-bahan pembius (anestesi) baik alami maupun buatan (Berka, 1986, dan Basyarie, 1990). Selama ini, pengusaha perikanan menggunakan teknik pemingsanan es batu, sayangnya teknik es batu tidak praktis dan tingkat kematian ikan sangat tinggi.
Ditinjau dari aspek komersial, teknik pemingsanan dengan menggunakan es batu kurang menguntungkan. Selain es batu, pengusaha juga menggunakan kontrol elektrik sederhana, penggunaan teknik ini masih ditemui masalah ketidakstabilan kondisi ikan dan waktu pingsan yang singkat.

Selain beberapa teknik pemingsanan dengan menggunakan es juga terdapat teknik pemingsanan dengan menggunakan minyak cengkeh dan pala. Berbagai penelitian mengenai kandungan minyak dalam buah pala sudah dilakukan di berbagai negara, salah satunya adalah penelitian yang dilakukan oleh Science and Technology Authority. Menurut para peneliti tersebut, kulit dan daging dari buah pala banyak mengandung minyak atsiri dan zat samak. Bagian fuli atau bunga pala juga mengandung zat yang hampir sama, yaitu atsiri, zat samak, dan zat pati, yang berkhasiat untuk mendorong keluarnya gas dalam usus, sekaligus dapat menenangkan saraf yang tegang, sebab fuli mengandung zat sedatif (penenang) sehingga dapat memingsankan ikan.

Kandungan berbagai zat dalam minyak yang dihasilkan oleh buah pala berguna untuk meredakan stres. Minyak pala merupakan salah satu jenis dari minyak atsiri yaitu Myristicin yang termasuk jenis alkohol seperti eugenol, yang juga terdapat dalam minyak cengkeh sehingga dapat membuat ikan lemas dan bergerak pelan dan akhirnya pingsan. Dari beberapa kajian tentang kandungan minyak pala, peneliti tertarik untuk melakukan penelitian tentang 
keefektifan minyak pala tersebut dalam hal memingsankan ikan. Sehingga dapat berkontribusi dalam menemukan bahan yang paling efektif dan efisien dalam memingsankan ikan untuk mengatasi masalah transportasi ikan budidaya terutama ikan nila.

\section{Tujuan dan Manfaat.}

Penelitian ini bertujuan untuk mengetahui pengaruh pemberian minyak pala dengan dosis yang berbeda terhadap pemingsanan ikan nila (Oreochromis niloticus) selama transportasi. Penelitian ini dapat dimanfaatkan oleh para petani dan pihak balai perikanan tentang teknik pemingsanan yang baik dan dengan dosis yang tepat.

\section{METODELOGI}

\section{Waktu Dan Tempat.}

Penelitian ini dilaksanakan pada tanggal 08 sampai 10 Agustus 2011 bertempat di Gampong Alue Keurinyai Kecamatan Banda Baro Kabupaten Aceh Utara.

\section{Alat dan Bahan.}

Alat yang digunakan dalam penelitian ini adalah 12 buah toples transparan dengan kapasitas 10 liter, 12 kotak Styrofoam ukuran 50 × 30 × $30 \mathrm{~cm}$ dengan ketebalan $2,5 \mathrm{~cm}$, kain lap, aerator, selang, stop watch, ember plastik, spuit (jarum suntik), dan pipet. Bahan yang digunakan adalah ikan nila, air tawar sebagai media, es, dan minyak pala.

\section{Metode Penelitian.}

Metode penelitian ini dilakukan dengan metode Rancangan Acak Lengkap (RAL) non faktorial dengan 4 perlakuan dan 3 ulangan. Perlakuan yang digunakan mengacu pada hasil penelitian pendahuluan dengan dosis terbaik 0,75 ppm, dengan perlakuan sebagai berikut:

\begin{tabular}{|c|c|c|c|c|c|}
\hline Perlakuan A & & minyak & pala & dengan & dosis \\
\hline Perlakuan B & & $\begin{array}{l}0,8 \text { ppm. } \\
\text { minyak }\end{array}$ & pala & dengan & dosis \\
\hline Perlakuan C & & $\begin{array}{l}\text { minyak } \\
1 \mathrm{ppm} .\end{array}$ & pala & dengan & dosis \\
\hline Perlakuan D & & $\begin{array}{l}\text { minyak } \\
1,1 \mathrm{ppm} .\end{array}$ & pala & dengan & dosis \\
\hline
\end{tabular}

\section{Prosedur Penelitian.}

\section{(1). Persiapan Wadah Penelitian.}

Wadah yang digunakan dalam penelitian ini adalah toples transparan yang berjumlah 12 buah berkapasitas 10 liter. Sebelum digunakan wadah dibersihkan terlebih dahulu dengan menggunakan air hangat, kemudian diisi air sebanyak 6 liter air. Selanjutnya dilakukan penambahan minyak pala sesuai dengan perlakuan yang sudah ditentukan pada wadah yang telah dipersiapkan.

\section{(2). Ikan Uji.}

Ikan uji diambil dari Gampong Bluka Teubai dalam keadaan hidup, sehat dan normal, dalam arti tidak dalam keadaan cacat, dengan ukuran siap panen atau \pm 150 gram/ ekor. Jumlah ikan per wadah adalah 4 ekor dengan jumlah total 48 ekor.

\section{(3). Aklimatisasi.}

Sebelum digunakan untuk penelitian, maka ikan nila diadaptasikan dahulu terhadap kondisi lingkungan penelitian. Proses adaptasi ini dilakukan selama 2 hari. Wadah untuk aklimatisasi, pemeliharaan dan pembiusan menggunakan toples transparan, aerator, dan diisi dengan air tawar dengan volume 30 liter/wadah.

\section{(4). Perlakuan Pada Ikan.}

Sebelum ikan nila dimasukkan ke dalam wadah yang telah diberikan air dan minyak pala, terlebih dahulu air dan minyak pala diaduk selama 2 menit dengan menggunakan aerasi. Setelah minyak pala dan air teraduk rata, ikan nila segera dimasukkan ke dalam wadah toples secara satu persatu sebanyak empat ekor ke setiap wadah yang telah diberikan minyak pala dengan dosis yang berbeda, kemudian respon ikan tersebut diamati.

\section{(5). Pengemasan Sebelum Transportasi.}

Persiapan wadah untuk proses pengemasan sebelum transportasi adalah kotak styrofoam diisi dengan es dengan perbandingan 2:1 (2 kg ikan dan 1 $\mathrm{kg}$ es) di ukur suhunya dan dilapisi dengan kain lap. Setelah persiapan wadah untuk transportasi selesai, ikan yang telah dipingsankan dimasukkan ke dalam kotak styrofoam, lalu disusun, dan ditutup, kemudian ikan siap ditransportasikan selama 3 jam. 


\section{Parameter Yang Diamati.}

\section{(1). Tingkah Laku Ikan.}

Parameter tingkah laku diamati secara visual setelah ikan uji dan minyak pala dimasukkan ke dalam wadah yang sama, setelah itu diamati tingkah lakunya sampai pingsan.

\section{(2). Lama Waktu Untuk Pingsan.}

Parameter ini diamati sejak ikan dimasukkan dalam wadah yang telah terisi minyak pala sampai ikan tersebut pingsan.

\section{(3). Lama Waktu Pingsan.}

Parameter ini diamati sejak ikan tersebut menjelang pingsan, kemudian ikan ditansportasikan selama 3 jam, kemudian dihitung waktu saat ikan disadarkan kembali dengan menggunakan aerator dan air tawar yang segar tanpa minyak pala.

\section{(4). Lama Waktu Sadar.}

Parameter ini diamati sejak ikan nila tersebut pingsan, kemudian disadarkan kembali setelah transportasi dengan menggunakan aerator dan air tawar yang segar tanpa minyak pala.

\section{(5). Survival Rate (SR).}

SR atau tingkat kelangsungan hidup dihitung dengan menggunakan rumus (Effendie, 1979) yaitu:

$$
\mathrm{SR}=(\mathrm{Nt} / \mathrm{No}) \times 100 \%
$$

Keterangan:

$\begin{array}{llll}\mathrm{SR} & \text { : Kelangsungan Hidup (\%) } & & \\ \mathrm{Nt} & \text { : Jumlah ikan yang hidup pada akhir } \\ & \text { penelitian (ekor) } \\ \mathrm{No} & \begin{array}{l}\text { : Jumlah ikan yang hidup pada awal } \\ \text { penelitian (ekor) }\end{array} & & \\ & \end{array}$

\section{Analisis Data.}

Model rancangan yang digunakan menurut Gomez dan Gomez (1995), adalah sebagai berikut:

$$
\mathbf{Y i j}=\boldsymbol{\mu}+\mathbf{U i}+\mathbf{K} \mathbf{j}+\sum \mathbf{i j}
$$

\section{Keterangan :}

Yi : Hasil pengamatan pengaruh penambahan minyak pala ke-K pada ulangan ke-i.

$\mu \quad$ : Pengaruh nilai tengah

U : Pengaruh ulangan ke- i

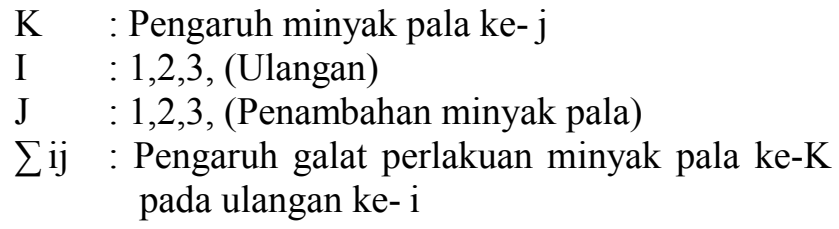

Data hasil Penelitian dianalisis dengan analysis of variance (anova) apabila menunjukkan $\mathrm{F}$ hitung $>\mathrm{F}_{\text {tabel, }}$ maka selanjutnya dilakukan uji lanjut dengan menggunakan Uji BNT.

\section{HASIL DAN PEMBAHASAN.}

\section{Tingkah Laku Ikan.}

Hasil penelitian pada perlakuan A menunjukkan bahwa reaksi ikan setelah dimasukkan ke dalam wadah yang sudah terisi minyak pala, ikan terlihat berenang aktif, dalam jangka waktu yang cukup lama yaitu pada menit ke 2':14" ikan terlihat sedikit panik, lalu terlihat stres pada menit ke 4':16" namun terkadang ikan terlihat diam dan tidak berenang. Berenangnya mulai miring pada menit ke $8^{\prime}: 45^{\prime \prime}$, tapi masih mampu bertahan, dan dalam jangka waktu 12':09" kemudian ikan roboh. Posisi ikan tegak lemah dan gerakan anggota badan seperti insang dan sirip masih jelas walaupun lemah dan jarang, serta masih responsif terhadap rangsangan fisik dari luar meskipun sudah lemah. Setelah itu ikan langsung terlihat tidak ada respon pada menit ke 19':03", ikan tersebut jatuh ke dasar wadah dan akhirnya pingsan, tapi gerakan insang dan sirip masih terlihat pada menit ke $26^{\prime}: 10^{\prime \prime}$.

Pada perlakuan B tidak jauh berbeda dengan perlakuan A, saat ikan dimasukkan ke dalam wadah yang sudah terisi minyak pala ikan terlihat berenang aktif, setelah menit ke 1 ':45" ikan terlihat diam. Lalu pada menit ke 2':13" ikan terlihat sedikit panik, dan pada menit ke 3':13" ikan tersebut sudah mulai stres, berenang miring pada menit ke $8^{\prime}: 26$ " tetapi masih mampu bertahan. Kemudian mulai roboh pada menit ke 12':07' posisi ikan tegak lemah dan gerakan anggota badan seperti insang dan sirip masih jelas walaupun lemah dan sesekali bergerak serta masih responsif terhadap rangsangan fisik dari luar. Setelah itu ikan pingsan pada menit ke 25':13" ikan tersebut jatuh ke dasar wadah, tapi gerakan insang dan sirip masih terlihat.

Pada perlakuan $\mathrm{C}$ juga tidak jauh berbeda dengan perlakuan $\mathrm{B}$, saat ikan dimasukkan ke dalam wadah yang sudah terisi minyak pala ikan pada 
menit ke 1':04" ikan terlihat diam. Lalu pada menit ke 1':24" ikan terlihat sedikit panik, dan pada menit ke 2':32" ikan tersebut sudah mulai stres, berenang miring pada menit ke $5^{\prime}: 34$ " dan kemudian mulai roboh pada menit ke 10':43". Setelah itu ikan pingsan pada menit ke 21':10" ikan tersebut jatuh ke bawah dasar wadah dan pingsan, tapi gerakan insang dan sirip masih terlihat.

Pada perlakuan D menunjukkan bahwa reaksi ikan setelah dimasukkan ke dalam wadah yang sudah terisi minyak pala, pada menit ke 1':12" awalnya panik, lalu terlihat stres pada menit ke 2':32' dan berenang miring pada menit ke 4':30'. Kemudian mulai roboh pada menit ke $11^{\prime}: 09$ ", pada menit ke 12':05" ikan tidak ada respon lagi. Setelah ikan pingsan, ikan tersebut jatuh ke dasar wadah, tapi gerakan insang dan sirip masih terlihat pada menit ke 13 ':08'. Hal ini sesuai dengan pendapat Karnila (2001), yaitu kondisi ikan terbius roboh serta tidak ada respon. Menurut Ningsih (2010) tingkah laku ikan sebelum pingsan antara lain panik, stres, berenang miring, dan kemudian pingsan, hal ini sesuai dengan perlakuan yang penulis lakukan.

Tabel 1. Lama waktu untuk pingsan ikan nila (Oreochromis niloticus).

\begin{tabular}{|c|c|c|c|c|}
\hline \multirow{3}{*}{ Perlakuan } & \multicolumn{3}{|c|}{ Lama waktu untuk pingsan } & \multirow{3}{*}{$\begin{array}{c}\text { Rata- } \\
\text { rata }\end{array}$} \\
\hline & & (menit) & & \\
\hline & $\begin{array}{c}\text { Ulangan } \\
\text { I }\end{array}$ & $\begin{array}{l}\text { Ulangan } \\
\text { II }\end{array}$ & $\begin{array}{c}\text { Ulangan } \\
\text { III }\end{array}$ & \\
\hline A & 26,12 & 26,09 & 26,10 & 26,10 \\
\hline B & 25,16 & 25,16 & 25,15 & 25,15 \\
\hline $\mathrm{C}$ & 21,12 & 21,13 & 21,12 & 21,12 \\
\hline D & 13,07 & 13,09 & 13,07 & 13,07 \\
\hline
\end{tabular}

Sumber: Data Penelitian, 2011.

\section{Keterangan:}

A: Minyak pala dengan dosis $0,8 \mathrm{ppm}$,

$\mathrm{B}$ : Minyak pala dengan dosis $0,9 \mathrm{ppm}$,

C: Minyak pala dengan dosis $1 \mathrm{ppm}$,

D: Minyak pala dengan dosis $1,1 \mathrm{ppm}$.

\section{Lama Waktu Untuk Pingsan.}

Hasil penelitian menunjukkan bahwa pemberian minyak pala dengan dosis yang berbeda berpengaruh terhadap waktu pingsan ikan nila. Dari hasil pengamatan ternyata ikan yang paling cepat pingsan adalah pada perlakuan D dengan dosis 1,1 ppm menunjukkan lama waktu untuk pingsan adalah pada menit 13':07', sedangkan lama waktu untuk pingsan pada perlakuan lain berturut-turut adalah $\mathrm{C}$ menit ke 21':12" B menit ke 25':15”, dan A menit ke $26^{\prime}: 10$ ”. Untuk selengkapnya dapat dilihat pada Tabel 1.

Berdasarkan Tabel 1 dapat dilihat bahwa perlakuan D dengan dosis 1,1 ppm merupakan perlakuan yang paling cepat pingsan, sedangkan selanjutnya disusul dengan perlakuan $\mathrm{C}$ : minyak pala dengan dosis $1 \mathrm{ppm}, \mathrm{B}$ : minyak pala dengan dosis $0,9 \mathrm{ppm}$, A: minyak pala dengan dosis $0,8 \mathrm{ppm}$.

Berdasarkan data lama waktu untuk pingsan selama penelitian pada Tabel 1 dapat diketahui bahwa lama waktu untuk pingsan pada perlakuan D dengan dosis $1,1 \mathrm{ppm}$ yang paling cepat pingsan bila dibandingkan dengan perlakuan $\mathrm{A}, \mathrm{B}$, dan $\mathrm{C}$. Uji analisa statistik menunjukkan bahwa lama waktu untuk pingsan dengan dosis minyak pala yang berbeda adalah berbeda sangat nyata, $F$ (hitung) $>F$ (tabel 0,01). Dengan menggunakan uji BNT (Beda Nyata Terkecil) didapatkan bahwa perlakuan D berbeda sangat nyata dengan perlakuan $C$, perlakuan $\mathrm{C}$ berbeda sangat nyata dengan perlakuan $\mathrm{B}$, dan perlakuan B berbeda sangat nyata dengan perlakuan A.

Diduga semakin tinggi dosis minyak pala maka semakin cepat ikan nila tersebut pingsan, dikarenakan dalam minyak pala mengandung eugenol yang juga terdapat dalam minyak cengkeh sehingga membuat ikan lemas dan akhirnya pingsan tetapi kandungan eugenol dalam minyak pala sangat rendah yaitu sekitar 4-8 \% bila dibandingkan dengan kandungan eugenol dalam minyak cengkeh yang mencapai $90 \%$. Hal ini sesuai dengan pendapat Afrianto dan Liviawati (1992), yaitu minyak cengkeh mengandung zat eugenol yang dapat membuat ikan lemas dan bergerak pelan dan akhirnya pingsan.

Hasil penelitian yang penulis lakukan hampir sama dengan hasil penelitian Wahyuni (2009) semakin tinggi dosis, waktu pingsan semakin cepat, tentang pengaruh minyak cengkeh terhadap lama waktu sebelum pingsan ikan bandeng yang paling cepat adalah pada perlakuan A dengan dosis $1 \mathrm{ml} / 5$ liter air yang membutuhkan waktu selama 58,33 detik.

Dari hasil penelitian Ningsih (2010) tentang pengaruh minyak cengkeh terhadap lama waktu menjelang pingsan ikan mas yang paling cepat pingsan adalah pada perlakuan A dengan dosis 1,3 $\mathrm{ml} / 7$ liter air yang membutuhkan waktu selama 58,48 detik. 


\section{Lama Waktu Pingsan.}

Hasil penelitian menunjukkan bahwa pemberian minyak pala dengan dosis yang berbeda berpengaruh terhadap lama waktu pingsan ikan nila. Pada perlakuan D dengan dosis 1,1 ppm merupakan lama waktu pingsan yang paling lama yaitu selama 253':09", kemudian disusul pada perlakuan lain seperti pada perlakuan C selama 230':30", perlakuan B selama 211':07', dan perlakuan A selama 204':06". Untuk lebih jelas dapat dilihat pada Tabel 2.

Tabel 2. Lama waktu pingsan ikan nila

\begin{tabular}{c|cccc}
\multicolumn{5}{c}{ (Oreochromis niloticus). } \\
\hline \multirow{3}{*}{ Perlakuan } & \multicolumn{4}{|c}{ Lama waktu pingsan (menit) } \\
& Ulangan & Ulangan & Ulangan & Rata- \\
& I & II & III & rata \\
\hline A & 204,55 & 204,40 & 204,45 & 204,46 \\
B & 211,10 & 211,07 & 211,05 & 211,07 \\
C & 230,29 & 230,33 & 230,30 & 230,30 \\
D & 253,06 & 253,08 & 253,13 & 253,09 \\
\hline
\end{tabular}

Sumber: Data Penelitian, 2011.

Berdasarkan Tabel 2 dapat dilihat bahwa perlakuan D dengan dosis 1,1 ppm merupakan perlakuan yang paling lama waktu pingsan, sedangkan selanjutnya disusul dengan perlakuan C: Minyak pala dengan dosis $1 \mathrm{ppm}, \mathrm{B}$ : Minyak pala dengan dosis $0,9 \mathrm{ppm}$, dan perlakuan A: Minyak pala dengan dosis $0,8 \mathrm{ppm}$.

Berdasarkan hasil pengamatan, dapat dijelaskan bahwa pada perlakuan D merupakan waktu yang paling lama ikan pingsan yaitu selama 253':09', kemudian disusul pada perlakuan C 230':30", perlakuan B selama 211':07', dan perlakuan A merupakan perlakuan yang paling singkat lama waktu pingsan diantara perlakuan yang lain yaitu selama $204^{\prime}: 46$ '.

Uji analisis menunjukkan bahwa lama waktu menjelang pingsan dengan dosis minyak pala yang berbeda adalah berbeda sangat nyata, $\mathrm{F}$ (hitung) $>\mathrm{F}$ (tabel 0,01). Dengan menggunakan uji BNT (Beda Nyata Terkecil) didapatkan bahwa perlakuan D berbeda sangat nyata dengan perlakuan $\mathrm{C}$, perlakuan $\mathrm{C}$ berbeda sangat nyata dengan perlakuan $\mathrm{B}$, dan perlakuan B berbeda sangat nyata dengan perlakuan A.

Hasil penelitian penulis hampir mirip dengan hasil penelitian Ningsih (2010) tentang semakin tinggi dosis yang diberikan maka semakin lama waktu pingsan ikan tersebut, pengaruh minyak cengkeh terhadap lama waktu pingsan ikan mas yaitu perlakuan yang paling lama pingsan adalah pada perlakuan A dengan 1,3 $\mathrm{ml} / 7$ liter air yang membutuhkan waktu selama 18060,28 detik.

Hasil penelitian menunjukkan bahwa waktu pemingsanan yang paling lama diperoleh pada penggunaan minyak cengkeh $15 \mathrm{mg} /$ liter air yaitu selama 79':40". Selanjutnya menjadi lebih cepat berturut-turut untuk konsentrasi $30 \mathrm{mg} /$ liter air yaitu selama $26^{\prime}: 55^{\prime}$ ", $45 \mathrm{mg} / \mathrm{liter}$ air yaitu selama 10':30" dan untuk $60 \mathrm{mg} / 1$ yaitu selama 8':00".

\section{Lama Waktu Sadar.}

Pada saat ikan nila dimasukkan ke dalam air untuk dilakukan penyadaran kembali ikan tersebut masih dalam keadaan pingsan, tetapi gerakan insang, sirip dan pangkal ekor sudah terlihat. Setelah beberapa saat kemudian, dan ikan tersebut sadar, bergerak pelan dan berenang perlahan, dan dalam jangka waktu tertentu ada ikan yang berenang aktif (normal kembali), dan ada juga beberapa ikan yang mati karena tidak mampu bertahan terhadap perlakuan dengan dosis minyak pala pada semua perlakuan.

Hasil penelitian menunjukkan bahwa pemberian minyak pala dengan dosis yang berbeda berpengaruh terhadap waktu sadar ikan nila, pada perlakuan D dengan dosis $1,1 \mathrm{ppm}$ merupakan lama waktu sadar yang paling lama yaitu pada menit ke 60':06”. Kemudian disusul dengan perlakuan C: 45':30" B: 30':12", dan perlakuan A selama: $24^{\prime}: 46$ ". Untuk lebih jelasnya dapat dilihat pada Tabel 3.

Tabel 3. Lama waktu sadar ikan nila (Oreochromis niloticus).

\begin{tabular}{c|cccc}
\hline \multirow{3}{*}{ Perlakuan } & \multicolumn{4}{|c}{ Lama waktu sadar } \\
& $\begin{array}{c}\text { Ulangan } \\
\text { I }\end{array}$ & $\begin{array}{c}\text { Ulangan } \\
\text { II }\end{array}$ & $\begin{array}{c}\text { Ulangan } \\
\text { III }\end{array}$ & $\begin{array}{c}\text { Rata- } \\
\text { rata }\end{array}$ \\
\hline A & 24,55 & 24,40 & 24,45 & 24,46 \\
B & 30,15 & 30,12 & 30,10 & 30,12 \\
C & 45,29 & 45,33 & 45,30 & 45,30 \\
D & 60,03 & 60,05 & 60,10 & 60,06 \\
\hline
\end{tabular}

Sumber: Data Penelitian, 2011.

Berdasarkan data lama waktu sadar pada Tabel 3, dapat dijelaskan bahwa lama waktu sadar yang paling lama terdapat pada perlakuan $\mathrm{D}$ dengan dosis 1,1 ppm yaitu pada menit ke 60':06', dibandingkan dengan perlakuan $\mathrm{C}, \mathrm{B}, \mathrm{A}$ masingmasing dengan lama waktu secara berturut-turut 
45':30"; 30':12' dan 24':46". Uji analisis statistik menunjukkan bahwa lama waktu menjelang pingsan dengan dosis minyak pala yang berbeda adalah berbeda sangat nyata, F (hitung) $>$ F (tabel 0,01). Dengan menggunakan uji BNT (Beda Nyata Terkecil) didapatkan bahwa perlakuan $\mathrm{D}$ berbeda sangat nyata dengan perlakuan $\mathrm{C}$, perlakuan $\mathrm{C}$ berbeda sangat nyata dengan perlakuan $\mathrm{B}$, dan perlakuan B berbeda sangat nyata dengan perlakuan A.

Dari hasil penelitian ternyata semakin tinggi dosis minyak pala yang diberikan maka semakin lama ikan nila tersebut sadar, dikarenakan dalam minyak pala mengandung zat eugenol yang juga terkandung dalam minyak cengkeh. Pada perlakuan A saat pembongkaran setelah transportasi selama 3 jam untuk proses penyadaran, pada saat dimasukkan ke dalam air segar yang ditambahkan aerasi. Ikan masih dalam keadaan roboh dan jatuh ke dasar wadah dan terlihat diam tanpa ada pergerakan sedikit pun, seolah-olah ikan mati yang masih segar.

Ikan yang tenang dan tidak bergerak tersebut merupakan ikan yang mati karena tubuhnya keras dan kaku pada saat pembiusan yang menyebabkan ikan tersebut menjadi mati, serta ditambah lagi akibat kelebihan dosis minyak pala yang tinggi sehingga mengakibatkan ikan tidak mampu bertahan (Berka,1986). Sedangkan penggunaan dosis minyak pala yang rendah lama waktu pingsan sangat singkat bila dibandingkan dengan pembiusan menggunakan minyak cengkeh, dikarenakan kandungan zat eugenol dan methyleugenol yang terkandung dalam minyak pala sangat rendah yaitu sekitar 4-8 \% (Drazat, 2007). Hal ini hampir mirip dengan hasil penelitian Wahyuni (2009) tentang pengaruh minyak cengkeh terhadap lama waktu sadar ikan mas yang paling lama pingsan adalah pada perlakuan A dengan $1 \mathrm{ml} / 5$ liter air yang membutuhkan waktu selama 435 detik, hal ini berbeda dengan perlakuan yang penulis lakukan. Waktu pemulihan yang paling lama diperoleh dari perlakuan konsentrasi minyak cengkeh $45 \mathrm{mg} / 1$ yaitu 7': 35" dan $60 \mathrm{mg} / 1$ yaitu 8':09", sedangkan waktu tercepat diperoleh pada konsentrasi $15 \mathrm{mg} / 1$ 1':72" dan $30 \mathrm{mg} / 1$ 2':68".

Pada perlakuan A ikan yang masih hidup mulai menunjukkan tanda-tanda kesadarannya, seperti adanya pergerakan pada insang, sirip dan pangkal ekor walaupun hanya sedikit, dan perlahan mulai menunjukkan pergerakan tubuhnya dan mulai berenang perlahan-lahan, dan lalu aktif kembali. Pada perlakuan B, C, dan D pada saat pembongkaran setelah transportasi selama 3 jam untuk proses penyadaran, pada saat dimasukkan ke dalam air segar yang ditambahkan aerasi, ikan masih dalam keadaan roboh dan jatuh ke dasar wadah dan terlihat diam tanpa ada pergerakan sedikitpun, seolah-olah ikan mati yang masih segar. Secara visual tubuh ikan terlihat keras dan kaku sehingga menyebabkan banyak ikan yang mati.

\section{Kelangsungan Hidup.}

Hasil penelitian menunjukkan bahwa tingkat kelangsungan hidup ikan nila adalah berbeda sangat nyata, F (hitung) $>$ F (tabel 0,01), rata-rata tingkat kelangsungan hidup untuk semua perlakuan sangat rendah yaitu sekitar 29,16\%. Perlakuan A dengan tingkat kelangsungan hidupnya 58,33\%, sedangkan perlakuan $\mathrm{B}$ adalah $33,33 \%$, perlakuan $\mathrm{C}$ adalah $16,66 \%$, dan perlakuan D adalah 8,33 \%. Hasil penelitian dapat dilihat pada Tabel 4 di bawah ini.

Tabel 4. Kelangsungan hidup ikan nila (Oreochromis niloticus).

\begin{tabular}{c|cccc}
\hline \multirow{3}{*}{ Perlakuan } & \multicolumn{4}{|c}{ Kelangsungan Hidup (\%) } \\
Ulangan & Ulangan & $\begin{array}{c}\text { Rata- } \\
\text { Ulangan }\end{array}$ & $\begin{array}{c}\text { rata } \\
(\%)\end{array}$ \\
\hline A & 75 & 50 & 50 & 58,33 \\
B & 25 & 50 & 25 & 33,33 \\
C & 25 & 0 & 25 & 16,16 \\
D & 0 & 25 & 0 & 8,33 \\
\hline
\end{tabular}

Sumber: Data Penelitian, 2011.

Berdasarkan Tabel 4, menunjukkan banwa tingkat kelangsungan hidup tertinggi pada perlakuan A yaitu $58,33 \%$, dan terendah pada perlakuan D yaitu $8,33 \%$. Hal ini dikerenakan dosis minyak pala yang diberikan terlalu tinggi yaitu 1,1 ppm.

Dari hasil penelitian tersebut dapat dijelaskan bahwa kelangsungan hidup ikan nila pada perlakuan A lebih tinggi bila dibandingkan dengan perlakuan B, C, dan D. Pada perlakuan B, C, dan D bila dilihat dengan rendahnya $\mathrm{SR}$, diduga dengan pemberian minyak pala yang banyak bisa mengakibatkan kematian. Minyak pala sebagai bahan penyedap pada produk makanan dianjurkan memakai dosis sekitar $0,08 \%$, karena dalam dosis yang lebih tinggi dapat menyebabkan keracunan. Minyak ini memiliki kemampuan lain, yaitu dapat mematikan serangga (insektisidal), anti jamur (fungisidal), dan anti bakteri.

Berdasarkan uraian hasil penelitian efektifitas dosis minyak pala untuk pemingsanan ikan nila (Oreochromis niloticus) selama transportasi diduga tidak efektif untuk pemingsanan ikan dikarenakan 
kelangsungan hidup untuk semua perlakuan sangat rendah yaitu sekitar 29,16 \%. Dosis tinggi akan menyebabkan banyak ikan yang mati sedangkan dosis rendah membutuhkan waktu yang sangat lama pada saat pembiusan menjelang pingsan, dan lama waktu pingsan sangat singkat bila dibandingkan dengan pembiusan menggunakan minyak cengkeh, dikarenakan kandungan zat eugenol dan methyleugenol yang terkandung dalam minyak pala sangat rendah yaitu sekitar 4-8 \% (Drazat, 2007). Hasil penelitian penulis sangat berbeda dengan hasil penelitian Ningsih (2010) tentang pengaruh minyak cengkeh terhadap kelangsungan hidup ikan mas (Cyprinus carpio) yang tertinggi terdapat pada perlakuan $\mathrm{B}$ dengan $1 \mathrm{ml} / 7$ liter air dengan nilai $100 \%$, C dengan $0,7 \mathrm{ml} / 7$ liter air dengan nilai $100 \%$, B dengan $0,4 \mathrm{ml} / 7$ liter air dengan nilai $100 \%$.

Selanjutnya untuk tingkat kelangsungan hidup (\%) ikan nila juga berpengaruh pada banyak sedikitnya aktifitas fisik pada saat dilakukan pembiusan. Ikan akan mengeluarkan lendir pada saat selama pengangkutan, karena pada saat pembiusan banyak ikan yang mengalami stres dan ikan menjadi menggelepar dengan banyaknya melakukan aktifitas fisik. Oleh sebab itu banyak menghabiskan energi, maka pada saat pengangkutan ikan akan mengeluarkan lendir.

Dapat dibuktikan pada saat pembongkaran dan pada saat dilakukan penyadaran ikan terasa licin dan berlendir. Adapun fungsi lendir untuk mencegah gesekan badan dengan air atau es, mempercepat gerakan saat penyadaran, mencegah keluar masuk air melalui kulit, mencegah infeksi, menutup luka, dan mencegah kekeringan.

\section{KESIMPULAN DAN SARAN.}

\section{Kesimpulan.}

Hasil Penelitian menunjukkan yang paling cepat pingsan adalah perlakuan D dengan dosis 1,1 ppm menunjukkan lama waktu untuk pingsan adalah pada menit $13^{\prime}: 08$ ", perlakuan $\mathrm{C}$ dengan dosis $1 \mathrm{ppm}$ menunjukkan lama waktu untuk pingsan adalah pada menit $21^{\prime}: 10$ ', perlakuan B dengan dosis $0,9 \mathrm{ppm}$ menunjukkan lama waktu untuk pingsan adalah pada menit 25':13", perlakuan A dengan dosis $0,8 \mathrm{ppm}$ menunjukkan lama waktu untuk pingsan adalah pada menit 26':10". Lama waktu pingsan yang paling cepat yaitu pada perlakuan A dengan dosis $0,8 \mathrm{ppm}$ air selama 204':46" menit, perlakuan B dengan dosis 0,9 ppm air selama 210':12", menit, perlakuan C dengan dosis 1 ppm selama 225':30" menit, perlakuan D dengan dosis 1,1 ppm selama 240':06" menit. Lama waktu sadar yang paling cepat yaitu pada perlakuan A dengan dosis $0,8 \mathrm{ppm}$ pada menit ke $24^{\prime}: 47^{\prime}$, perlakuan B dengan dosis $0,9 \mathrm{ppm}$ pada menit ke $30^{\prime}: 20$ ", perlakuan $\mathrm{C}$ dengan dosis $1 \mathrm{ppm}$ air pada menit ke $45^{\prime}: 51^{\prime}$ ', perlakuan D dengan dosis 1,1 ppm pada menit ke 60':06". Perlakuan A dengan tingkat kelangsungan hidupnya $58,33 \%$, sedangkan perlakuan $\mathrm{B}$ adalah 33,33 \%, perlakuan $\mathrm{C}$ adalah $16,66 \%$, dan perlakuan D adalah 8,33\%.

Berdasarkan uraian hasil penelitian efektifitas dosis minyak pala untuk pemingsanan ikan nila (Oreochromis niloticus) selama transportasi dapat disimpulkan bahwa minyak pala di berbagai dosis tidak efektif untuk pemingsanan ikan dikarenakan kelangsungan hidup rata-rata untuk semua perlakuan sangat rendah yaitu sekitar 29,16\%. Dosis tinggi akan menyebabkan banyak ikan yang mati sedangkan dosis rendah membutuhkan waktu yang sangat lama pada saat pembiusan menjelang pingsan, dan lama waktu pingsan sangat singkat bila dibandingkan dengan pembiusan menggunakan minyak cengkeh.

\section{Saran.}

Perlu dilakukan penelitian tentang efektifitas dosis minyak atsiri yang lain untuk pemingsanan ikan agar didapat kelangsungan hidup yang tinggi.

\section{DAFTAR PUSTAKA.}

Afrianto, E., \& E. Liviawati. (1992). Pengendalian hama dan penyakit ikan. Kanisius. Yogyakarta.

Basyarie, A. (1990). Transportasi ikan hidup. Training Penangkapan. Aklimatisasi dan Transportasi Ikan Hias Laut. Jakarta 4-18 Desember 1990.

Berka, R. (1986). The transport of live fish. EIFAC Teach. Pap., FAO, (48) : 48-52.

Drazat. (2007). Meraup laba dari pala. Agromedia Pustaka. Jakarta.

Effendie. (1979). Metode biologi perikanan. Dwi Sri. Bogor. 
Gomez, A. A., \& Gomez, K. A. (1995). Prosedur statistik untuk penelitian pertanian. Universitas Indonesia. Jakarta.

Karnila. (2001). Pengaruh suhu dan waktu pembiusan bertahap terhadap ketahanan hidup ikan jambal siam (Pangasius sutchi $\mathrm{F}$ ) dalam transportasi sistem kering. Natur Jurnal Indonesia. Fakultas Perikanan dan Ilmu Kelautan. Universitas Riau.

Ningsih, T. (2010). Kajian penggunaan minyak cengkeh (Syzygium aromatikum) dengan dosis yang berbeda terhadap waktu pingsan ikan mas (Cripinus carpio) selama transportasi dalam media serbuk gergaji. Skripsi. Program Studi Budidaya Perairan, Fakultas Pertanian, Universitas Malikussaleh.

Wahyuni, (2009). Pengaruh konsentrasi minyak cengkeh yang berbeda terhadap waktu pingsan ikan bandeng (Chanos chanos). Skripsi. Program Studi Budidaya Perairan, Fakultas Pertanian. Universitas Malikussaleh. 